\title{
Sub-canopy light conditions only allow low annual net productivity of epiphytic algae on kelp Laminaria hyperborea
}

\author{
Morten F. Pedersen ${ }^{1, *}$, Lars B. Nejrup ${ }^{1}$, Troels M. Pedersen ${ }^{1}$, Stein Fredriksen ${ }^{2}$ \\ ${ }^{1}$ Department for Environmental, Social and Spatial change (ENSPAC), Roskilde University, Universitetsvej 1, PO Box 260, \\ 4000 Roskilde, Denmark \\ ${ }^{2}$ University of Oslo, Department of Biosciences, PO Box 1066, Blindern, 0316 Oslo, Norway
}

\begin{abstract}
The stipes of older Laminaria hyperborea individuals are heavily covered by epiphytic assemblages that are dominated by macroalgae, and we hypothesized that the production of these algae may contribute significantly to total primary production of the kelp forest ecosystem. The epiphytic assemblages on the stipes of Laminaria were dominated by potentially fastgrowing red algae with total biomass ranging from 25 to $120 \mathrm{~g}$ dry weight (DW) m${ }^{-2}$ seafloor depending on season and site. Sub-canopy light conditions were poor and averaged only $\sim 10 \%$ of the surface irradiance in summer. Photosynthetic profiles of the epiphytic assemblages indicated that they were acclimated to shade, and the poor sub-canopy light conditions were nevertheless sufficient to ensure positive net photosynthesis for at least 2 to $3 \mathrm{~h}$ daily throughout the year. Photosynthetic efficiency at low light and dark respiration varied seasonally, which led to a threefold increase in minimum light requirements in early fall, simultaneously with high water temperatures and declining surface irradiance. This resulted in low productivity and net carbon loss from September throughout winter. Net productivity became positive in February-March and rose through spring as surface irradiance increased. Annual net productivity was relatively low, ranging from 42 to $96 \mathrm{~g} \mathrm{DW} \mathrm{m}^{-2}$ seafloor depending on site. We conclude that the net productivity of these macroalgal epiphytes is insignificant relative to that of kelp itself, and that the large observed biomass needs several years to accumulate.
\end{abstract}

KEY WORDS: Epiphytes $\cdot$ Species composition $\cdot$ Primary production

Resale or republication not permitted without written consent of the publisher

\section{INTRODUCTION}

Laminaria hyperborea is the dominant kelp species along the west coast of Norway where it is estimated to cover an area of ca. $6000 \mathrm{~km}^{2}$ (Gundersen et al. 2010). The Norwegian kelp forests are highly productive, with annual primary production reaching 1000 to $3000 \mathrm{~g}$ dry weight (DW) $\mathrm{m}^{-2}$ (e.g. Abdullah \& Fredriksen 2004, Pedersen et al. 2012). These kelp forests support a rich fauna that uses kelp and associated macroalgae as substrate, food and shelter (Norderhaug 2004, Christie et al. 2009).
The stipe of older Laminaria individuals serves as substrate for large epiphytic communities. These epiphytic communities are comprised of bacteria, protozoans, microalgae and macroalgae, which dominate the biomass of the communities (Norton et al. 1977, Whittick 1983, Schultze et al. 1990, Norderhaug et al. 2012). The macroalgal assemblage is dominated by red algae (Rhodophyta), and the total biomass of macroalgae on the stipes of $L$. hyperborea may range from 5 to $60 \mathrm{~g} \mathrm{DW}$ stipe $^{-1}$, depending on host age, depth, season and wave exposure (Norton et al. 1977, Whittick 1983). The density of tall, canopy-forming 
L. hyperborea ranges typically from 5 to $15 \mathrm{~m}^{-2}$ (Rinde \& Sjøtun 2005, Pedersen et al. 2012), so the biomass of epiphytes per unit area of seafloor may potentially range from 25 to $900 \mathrm{~g} \mathrm{DW} \mathrm{m}^{-2}$, corresponding to that of fast-growing ephemeral macroalgae in eutrophic estuarine areas (e.g. Valiela et al. 1997).

Most of the epiphytic macroalgae found on L. hyperborea are relatively small (i.e. thin) species with higher maximum photosynthetic rates and faster growth than L. hyperborea (Johansson \& Snoeijs 2002). One hypothesis is, therefore, that the large biomass combined with potential fast growth would allow these epiphytes to contribute significantly to the total productivity of these kelp forests. On the other hand, L. hyperborea forms a dense canopy layer that attenuates light. Norton et al. (1977) thus showed that the canopy layer caught 87 to $91 \%$ of the available light in a Scottish L. hyperborea kelp forest. This report suggests that sub-canopy epiphytes are light limited and, thereby, their net productivity may be low.

Recent studies have shown that the biomass of macroalgal epiphytes on the stipe of L. hyperborea correlates with wave exposure, but the underlying reason for this relation remains unknown (Norderhaug et al. 2012). The positive correlation suggests that sub-canopy light availability improves with increasing wave exposure or, alternatively, that loss processes (e.g. by grazing and/or detachment) are inversely related to wave exposure. Light availability below the canopy may indeed improve with increasing wave exposure in some kelp species. Gerard (1984) and Wing et al. (1993) showed that wave induced movement of the floating canopy of Macrocystis pyrifera resulted in a higher light penetration through the canopy and improved light conditions at the seafloor. The morphology of Macrocystis differs, however, from that of L. hyperborea, which has a much shorter stipe ( 1 to $3 \mathrm{~m}$ ) and only one big frond with an area of 0.5 to $1.0 \mathrm{~m}^{2}$. Hydrodynamics may therefore affect the canopy of these 2 species differently, thus potentially creating different light conditions at sub-canopy levels.

The major aims of this study were to describe light conditions and quantify the productivity of epiphytic macroalgae within the $L$. hyperborea forest. We hypothesized that enough light is available below the canopy to support substantial growth of the epiphytes, and that this may contribute significantly to total primary production in the kelp forest. We further expected that sub-canopy light conditions improve with increasing wave exposure, which could explain why the biomass of epiphytic macroalgae is larger at sites with high wave exposure.

\section{MATERIALS AND METHODS}

\section{Study site}

This study was carried out in the Molde archipelago $\left(62^{\circ} 50^{\prime} \mathrm{N}, 06^{\circ} 30^{\prime} \mathrm{E}\right)$ on the west coast of Norway (Fig. 1). The westward coastlines of the outermost islands (facing the Norwegian Sea) are exposed to waves and ocean swells, while sheltered sites are found on the eastern sides of the islands. Laminaria hyperborea is the most abundant kelp species in the area where it dominates the sub-littoral flora in the depth range from 3 to $20 \mathrm{~m}$ (Bekkby et al. 2008). Six study sites were chosen to represent 2 levels of wave exposure (low and high) with 3 replicate sites for each level. Sites with different levels of wave exposure were identified from GIS-maps of relative wave exposure (RWE) in the area. RWE was mapped with a spatial resolution of $10 \mathrm{~m}$ using a 'simplified wave model' (Eq. 1) that uses fetch, wind speed and frequency in 16 compass directions as input data (Isæus 2004, Bekkby et al. 2008):

$$
\mathrm{RWE}=\frac{1}{16} \sum_{i=1}^{16} F_{i} \times W_{i} \times f_{i}
$$

where $F_{i}$ is fetch (in $\mathrm{m}$ ), $W_{i}$ is the average wind speed (in $\mathrm{m} \mathrm{s}^{-1}$ ) and $f_{i}$ is the wind frequency (i.e. the relative

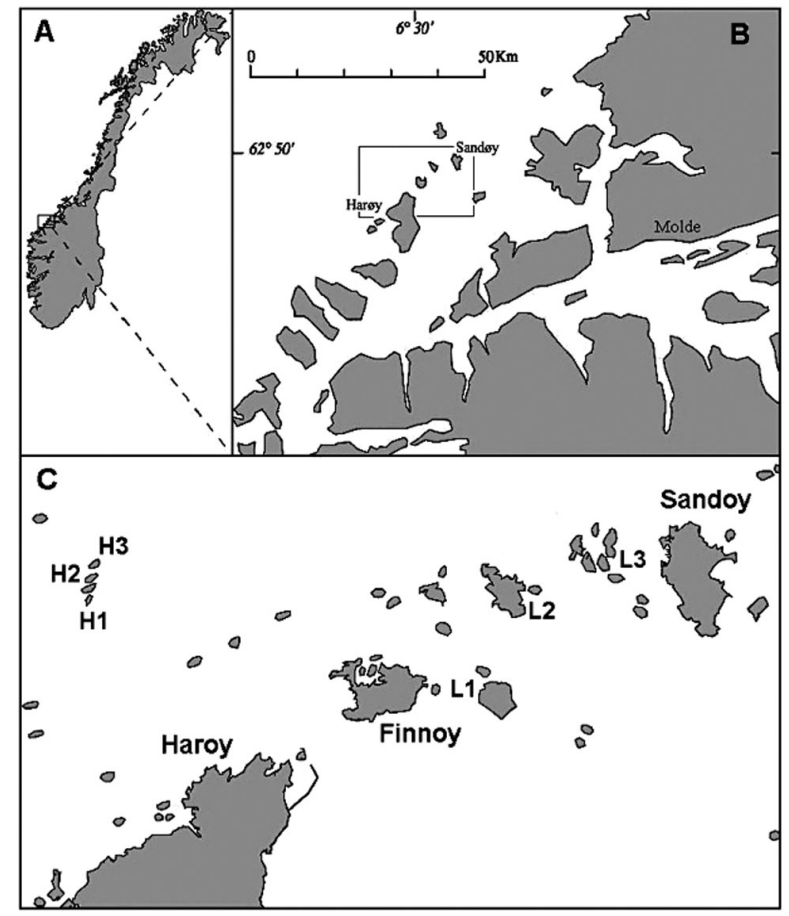

Fig. 1. (A) Norway and (B) the Molde archipelago with an indication of (C) the 6 study sites situated around and between the islands of Haroy, Finnoy and Sandoy 
amount of time that the wind came from direction $i$ ) in compass sector $i$. Data for wind speed and direction were obtained from the Norwegian Meteorological Institute and averaged over a 5 yr period (20012005). Predicted levels of wave exposure ranged from 'sheltered' to 'very exposed' according to the system for coastal habitat classification in Europe (EUNIS; Davies et al. 2003).

The study was carried out during 3 intensive sampling events in April, June and September of 2006. The 3 months were chosen to represent typical spring, summer and fall conditions, and a respective sampling event was conducted for each season. During each sampling event we measured the density and frond biomass of L. hyperborea (canopy plants only), the biomass, species composition and photosynthetic capacity of epiphytic macroalgae on the stipe of L. hyperborea and, finally, the light conditions in the kelp forest.

\section{Light conditions}

Duplicate sets of light and temperature loggers (HOBO Pendant Temperature/Light Data logger 64K, Onset Computer Cooperation) were deployed at each site during each sampling event. Each set consisted of 3 loggers placed on a vertically oriented line that was held in place by an anchor and a buoy. One logger was located right above the canopy layer of the kelp forest, and one was situated halfway between the canopy layer and the sea floor (i.e. 45 and $60 \mathrm{~cm}$ above the sea floor at sites with low and high wave exposure, respectively) while the final logger was located on the sea floor. The 36 deployed loggers recorded light intensity and temperature every $5 \mathrm{~min}$ for 7 to 10 successive days during each sampling event. Surface irradiance was measured as photosynthetically active radiation (PAR) using a $2 \pi$ LiCor censor (LiCor Li-192SA, connected to a LiCor Li-1000 light meter) that was placed on the roof of the field station during the same periods. HOBO loggers measure light in units of Lumen $\mathrm{m}^{-2}$, not in PAR ( $\mu$ mol photons $\mathrm{m}^{-2} \mathrm{~s}^{-1}$ ). Readings from the submerged HOBO loggers were therefore converted to PAR using the under-water calibration (Eq. 2) provided by Long et al. (2012). This calibration uses an exponential decay fit:

$$
\mathrm{PAR}=-2202.3 \times \mathrm{e}^{(-\mathrm{HOBO} / 26855.2)}+2037.8
$$

where PAR is the irradiance data from the LiCor logger ( $\mu$ mol photons $\mathrm{m}^{-2} \mathrm{~s}^{-1}$ ) and HOBO is the data from the HOBO logger (Lumen $\mathrm{m}^{-2}$ ).

\section{Collection of plants}

At each site, SCUBA divers collected all specimens of Laminaria hyperborea within 4 haphazardly placed frames (area: $1 \mathrm{~m}^{2}$ each) at a depth of 5 to $7 \mathrm{~m}$. The plants were brought back to the field station where they were aged (Kain 1963) and the relative abundance of macroscopic epiphytes on the stipe was determined visually according to a scale ranging from 0 to 4 ( $0=$ no visible epiphytes; $1=1-25 \%$ covered; $2=26-50 \% ; 3=51-75 \%$; and $4=76-100 \%$ covered). Stipe length and frond biomass (fresh weight; FW) were recorded for all canopy plants, i.e. plants taller than 60 and $80 \mathrm{~cm}$ at low and high exposure sites, respectively (Pedersen et al. 2012). At each site, 3 canopy individuals were chosen haphazardly and used for measuring photosynthetic parameters, biomass and species composition of the epiphytic algae.

\section{Photosynthetic light response (PI) curves}

PI-curves were made on 3 replicate stipes with associated and intact epiphytic assemblages from each study site during each sampling event (i.e. 18 stipes in total per sampling event). The frond and the holdfast were first removed and the stipe was cut into 2 equally sized halves (upper and lower half). Each half was placed in one of 2 cylindrical, gastight and transparent acrylic chambers (diameter $\times$ length $=5.5 \times 43 \mathrm{~cm}$, volume including tubing for pump = $1.15 \mathrm{l}$ ). A circulation pump (AquaBee, $300 \mathrm{l}$ $\mathrm{h}^{-1}$ ) was mounted on the side of each chamber to ensure circulation of water within the chamber (laminar flow $\sim 4 \mathrm{~cm} \mathrm{~s}^{-1}$ ). The chambers were filled with freshly collected and filtered (GF/C) seawater (salinity 30-32) from the collection site. The seawater was initially bubbled with $\mathrm{N}_{2}$ to reduce the initial $\mathrm{O}_{2}$ concentration to $60-70 \%$ of air saturation to prevent super-saturation of $\mathrm{O}_{2}$ during incubations. The chambers were closed and submerged into a water bath (dimensions: $40 \times 50 \times 30 \mathrm{~cm}$ ) with a constant temperature. Incubation temperatures were identical to those in situ at the time of collection, i.e. $6^{\circ} \mathrm{C}$ in April, $9^{\circ} \mathrm{C}$ in June and $16^{\circ} \mathrm{C}$ in September. The water bath held 2 replicate chambers at a time, each with one of the 2 half stipes from the same plant. Chambers were illuminated from above by a lamp with 6 halogen spots (OSRAM Decostar 51; $12 \mathrm{~V}, 35 \mathrm{~W}$ ), and $11 \mathrm{lev-}$ els of irradiance $(0,0.6,1.4,2.0,3.0,4.6,6.2,9.9,16.2$, 27.8 and $64.6 \mu \mathrm{mol}$ photons $\mathrm{m}^{-2} \mathrm{~s}^{-1}$ PAR) obtained using neutral density screens. Dark respiration was 
always measured first, followed by measurements at increasing levels of light.

Photosynthetic rates were measured as $\mathrm{O}_{2}$ release or consumption. Each chamber was equipped with a Clark-type $\mathrm{O}_{2}$ microelectrode (OX-500, Unisense) connected to a pico-amperemeter (Picoammeter PA2000, Unisense) and a Pico Technology ADC-16 high-resolution data logger. $\mathrm{O}_{2}$ concentrations were recorded every minute throughout the incubations. Rates of $\mathrm{O}_{2}$ consumption or release were calculated from incubation periods with constant changes in $\mathrm{O}_{2}$ concentration over a minimum of 10 min. Photosynthetic parameters $\left(P_{\max }, \alpha\right.$ and $\left.R_{\mathrm{D}}\right)$ were estimated by fitting Eq. (3) (Baly 1935) to the data using least square non-linear regression:

$$
P^{\mathrm{N}}=P_{\text {max }}^{\mathrm{N}} \times\left(1-\mathrm{e}^{\left(\frac{-\alpha \times I}{P_{\max }}\right)}\right)+R_{\mathrm{D}}
$$

where $P^{\mathrm{N}}$ is the net photosynthetic rate, $P^{\mathrm{N}}$ max is the maximum photosynthetic rate, $\alpha$ is the light utilization efficiency (at low light), $I$ is the irradiance and $R_{\mathrm{D}}$ is the dark respiration rate. The light compensation point $\left(I_{C}\right)$ was estimated using linear regression on 6 to 8 data points obtained at low light (range: 0-9.9 $\mu \mathrm{mol}$ photons $\mathrm{m}^{-2} \mathrm{~s}^{-1}$ ) while the light saturation point $\left(I_{\mathrm{K}}\right)$ was estimated as the intercept between $\alpha$ and $P_{\max }$ (i.e. $I_{\mathrm{K}}=P_{\max } / \alpha$ ). Eq. (3) was chosen among several alternative PI-models (Henley 1993) as it yielded the best fit to the data (i.e. highest $\mathrm{R}^{2}$-values).

In April, we conducted a few PI-measurements on stipes where the epiphytes had been scraped off to test if the stipe itself contributed significantly to respiration or photosynthesis. We were unable to measure any significant changes in $\mathrm{O}_{2}$ concentration during these incubations, and therefore assumed that older stipes, like those used in the measurements (Table 1), neither contributed substantially to respiration nor to photosynthesis. No further measurements with 'clean' stipes were carried due to logistic constraints (i.e. lack of time at the field site).
The epiphyte assemblages contained a few larger, sessile animals (tunicates and marine sponges) that could not be removed without destroying the algae. These animals were collected from each assemblage after the incubations and their respiration was measured and used to correct the obtained photosynthetic rates. Photosynthesis was measured in units of $\mu \mathrm{mol}$ $\mathrm{O}_{2}$ stipe $^{-1} \mathrm{~min}^{-1}$. Rates were converted to units of $\mu$ mol C stipe ${ }^{-1} \mathrm{~min}^{-1}$ assuming an average PQ-ratio of 1.15 for red algae (estimated from data in Buesa 1980, Thomas \& Wiencke 1991, Rosenberg et al. 1995) and, finally, to units of $\mathrm{g}$ DW stipe ${ }^{-1} \mathrm{~min}^{-1}$ assuming an average $\mathrm{C}$-content in macroalgae equal to $40 \%$ of DW (Duarte 1992).

\section{Epiphyte biomass and species composition}

Biomass and species composition were finally determined on all stipes used for the PI-measurements. Epiphytes were carefully scraped off the stipe with a sharp knife, sorted by species and identified. The DW biomass of each species was determined after drying the samples to constant weight at $80^{\circ} \mathrm{C}$.

\section{Net primary productivity}

Daily net productivity (NP) was calculated for each site and sampling event from data regarding in situ light availability and the obtained photosynthetic parameters using Eq. (3). The availability of light decreased substantially from below the canopy to the seafloor. We therefore estimated the light intensity for each $10 \mathrm{~cm}$ interval (between the canopy and the seafloor) while assuming exponential light attenuation with depth:

$$
I_{Z}=I_{0} \times \mathrm{e}^{(-\mathrm{k} \times Z)}
$$

where $I_{Z}$ is light at depth $Z$ below the canopy, $I_{0}$ is the light intensity just below the canopy layer (i.e. at $Z=$

Table 1. Laminaria hyperborea. Age, density, stem length, blade biomass and estimated leaf area index (LAI) of canopy plants from sites with low and high wave exposure and in different seasons, respectively. Data are means \pm 1 SD (across replicate sites; $\mathrm{n}=3$ )

\begin{tabular}{|lcccccc|}
\hline Month & $\begin{array}{c}\text { Wave } \\
\text { exposure }\end{array}$ & $\begin{array}{c}\text { Age } \\
(\mathrm{yr})\end{array}$ & $\begin{array}{c}\text { Density } \\
\left(\mathrm{m}^{-2}\right)\end{array}$ & $\begin{array}{c}\text { Stem length } \\
(\mathrm{cm})\end{array}$ & $\begin{array}{c}\text { Blade biomass } \\
\left(\mathrm{g} \mathrm{FW} \mathrm{m}^{-2}\right)\end{array}$ \\
\hline Apr & Low & $4.9 \pm 0.6$ & $11.5 \pm 2.5$ & $58.8 \pm 19.2$ & $1853 \pm 788$ & $1.83 \pm 0.80$ \\
& High & $5.7 \pm 0.6$ & $11.5 \pm 2.5$ & $104.8 \pm 19.7$ & $2021 \pm 406$ & $1.57 \pm 0.31$ \\
Jun & Low & $5.0 \pm 0.4$ & $9.9 \pm 3.4$ & $71.8 \pm 12.5$ & $3779 \pm 1249$ & $3.74 \pm 1.24$ \\
& High & $5.7 \pm 0.1$ & $10.5 \pm 1.0$ & $100.4 \pm 5.3$ & $5170 \pm 334$ & $4.01 \pm 0.26$ \\
Sep & Low & $4.3 \pm 0.1$ & $6.3 \pm 2.0$ & $69.4 \pm 26.2$ & $2307 \pm 747$ & $2.28 \pm 0.74$ \\
& High & $5.0 \pm 0.5$ & $13.1 \pm 2.8$ & $106.1 \pm 20.8$ & $6467 \pm 1044$ & $5.01 \pm 0.81$ \\
\hline
\end{tabular}


$0 \mathrm{~cm}$ ), and $k$ is the light attenuation coefficient. Site and season-specific light attenuation coefficients were calculated from the light intensity recorded by the loggers located below the canopy and on the sea floor using Eq. (4).

Epiphyte NPP per stipe was calculated for each $10 \mathrm{~cm}$ stipe interval (from the canopy to the seafloor) assuming an equal distribution of the epiphytes along the stipe. The biomass of epiphytes did not differ systematically between the lower $(2.43 \pm 1.82 \mathrm{~g}$ DW) and upper $(3.77 \pm 3.40 \mathrm{~g}$ DW) halves of the stipes (ANOVA, $F=3.85, \mathrm{n}=27, \mathrm{p}=0.053$ ). Estimates of epiphytic NP per stipe were made for each $5 \mathrm{~min}$ interval (equal to intervals of light measurement) throughout each sampling event. The estimates were summed and subsequently divided by number of days (during that sampling event) to yield average daily NPP per stipe at each site (g DW stipe $\mathrm{C}^{-1} \mathrm{~d}^{-1}$ ). NPP per unit area of seafloor (g DW m ${ }^{-2} \mathrm{~d}^{-1}$ ) was finally calculated for each site by multiplying sitespecific estimates of daily NPP per stipe with the sitespecific density of canopy plants $\left(\mathrm{m}^{-2}\right)$.

We estimated average daily NPP across each month during 2006 from data on surface insolation (see Fig. 3), observed light attenuation in the water column and by the canopy during sampling events (see Fig. 5), the obtained photosynthetic variables (see Fig. 7) and plant density (Table 1). Relative light penetration through the water column and the canopy layer was estimated for each month by interpolation from the observed relative light penetration (i.e. percentage of surface irradiance) during the sampling events in April, June and September. Photosynthetic variables $\left(P_{\max }, \alpha\right.$ and $R_{\mathrm{D}}$ ) obtained in April, June and September, respectively, were used to estimate net primary production (NPP) of the epiphytic assemblage in months with approximately the same water temperature, assuming that water temperature was the major cause for seasonal changes in $P_{\max }$ and $R_{\mathrm{D}}$ (e.g. Santamaría \& van Vierssen 1997).

\section{Statistical treatment}

A 2 or 3 factor permutational ANOVA was used to test the effect of wave exposure (2 levels: low and high, fixed) and season (3 levels: spring, summer and fall, fixed) on various response parameters, i.e. light availability in the kelp forest, photosynthetic parameters $\left(P_{\max }, \alpha, R_{\mathrm{D}}\right.$ and $\left.I_{\mathrm{C}}\right), \mathrm{NPP}$, biomass and species diversity of the epiphytes using Euclidian distances as a distance measure. Permutational
MANOVA was used to test the effect of wave exposure and season on species composition of the epiphytes using Bray-Curtis dissimilarity as a distance measure on square root transformed data. The permutational analyses were conducted by the PERMANOVA package in PRIMER+ (Anderson et al. 2008). We used Type III sum of squares and unrestricted permutations (9999) on raw data $(\alpha=0.05)$. SIMPER analysis from the same package was subsequently used to identify the species that contributed most to the observed difference in community composition among levels of wave exposure and/or season. Non-linear least square regression was used to fit the model in Eq. (3) to data for photosynthesis at different levels of light using SPSS statistical software.

\section{RESULTS}

\section{Kelp forest characteristics}

The average density of canopy plants ranged from 6.3 to 13.1 plants $\mathrm{m}^{-2}$ and tended to be higher at sites with high wave exposure, albeit not significantly (Table 1). The lamina biomass ranged from 1853 to $6467 \mathrm{~g} \mathrm{FW} \mathrm{m}^{-2}$ and was largest at sites with high wave exposure. Average lamina biomass (across sites) increased from April $\left(\sim 1900 \mathrm{FW} \mathrm{m}^{-2}\right)$ to September $\left(\sim 4350 \mathrm{~g} \mathrm{FW} \mathrm{m}^{-2}\right)$. The leaf area index (LAI) was estimated from the frond biomass and weight: area ratios published by Sjøtun \& Fredriksen (1995). LAI increased from April to September and was higher at sites with high wave exposure. The relative cover of epiphytes on the stipes increased with age, being almost completely absent on plants younger than $3 \mathrm{yr}$ and increasing to rank 3 in plants older than 7 yr (Fig. 2).

\section{Light conditions in the kelp forest}

Daily surface irradiance measured from the roof of the field station ranged from $\sim 0.2 \mathrm{~mol}$ photons $\mathrm{m}^{-2}$ in December/January to $\sim 49 \mathrm{~mol}$ photons $\mathrm{m}^{-2}$ in May, while the water temperature ranged from $5.6^{\circ} \mathrm{C}$ in March to $16.1^{\circ} \mathrm{C}$ in August (Fig. 3). Insolation varied substantially from day to day and between the sampling events (Fig. 4A). Daily surface irradiance during the 3 samplings averaged $20.2 \pm 6.7$ mol photons $\mathrm{m}^{-2}$ (mean $\pm 1 \mathrm{SD}$ across days) in April, $28.5 \pm 12.4$ and $12.2 \pm 7.5 \mathrm{~mol}$ photons $\mathrm{m}^{-2}$ in June and September, respectively. 


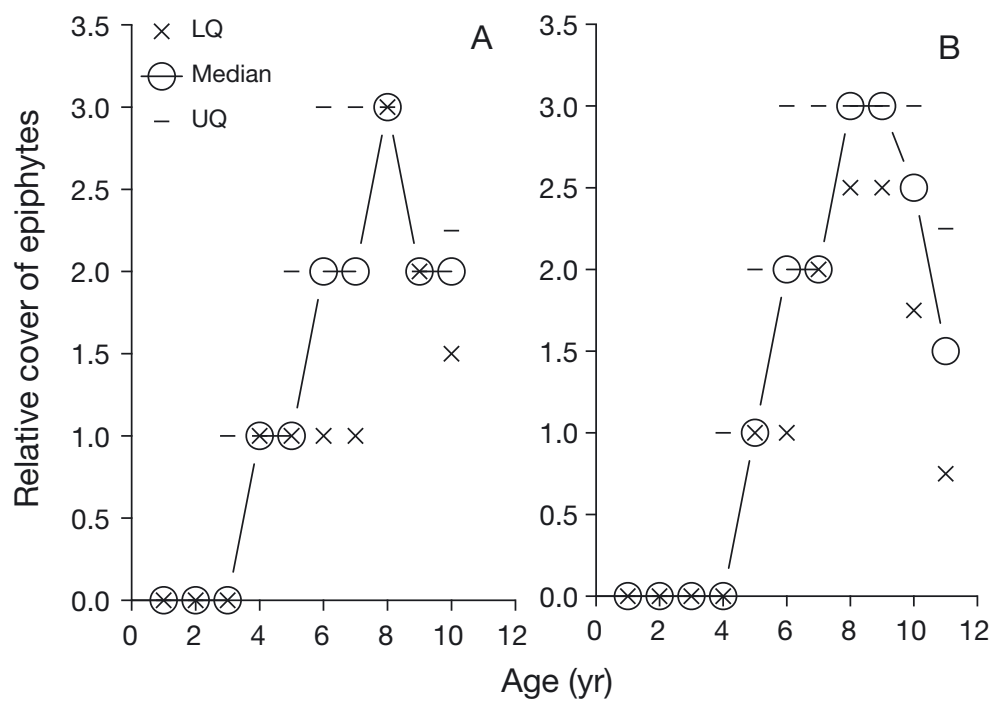

Fig. 2. Relative abundance (cover rank) of epiphytes on the stipe of Laminaria hyperborea at sites with (A) low and (B) high wave exposure. LQ: lower quartiles; UQ: upper quartiles. Observations are based on all individuals of $L$. hyperborea sampled at 3 sites and 3 sampling events with low wave exposure $(n=980)$ and 3 sites and 3 sampling events with high wave exposure $(\mathrm{n}=3031)$

Light intensity was reduced in the water column and by the canopy of Laminaria hyperborea (Fig. 4B). The light intensity measured just above the canopy layer increased from April to June and decreased substantially from June to September (pairwise comparisons; all p < 0.035). Between 66 and $88 \%$ of surface irradiance reached the canopy at low and high exposure sites in April and June, while $<45 \%$ reached the canopy in September (Fig. 5). The amount of light reaching the canopy did not differ among sites with low and high wave exposure in spring and fall (pairwise comparisons; all p > 0.116), but was higher at high exposure sites in summer (pairwise comparison; $\mathrm{p}=0.011$ ).

The canopy layer caught much of the incoming light: $<26 \%(10.7-26.0 \%)$ of the light reaching the canopy penetrated through the layer, and light intensity below the canopy corresponded only to $5-19 \%$ of the surface irradiance depending on site and season. Light intensity below the canopy never exceeded $60 \mu \mathrm{mol}$ photons $\mathrm{m}^{-2} \mathrm{~s}^{-1}$, and the cumulative daily photon flux ranged from 0.7 to $3.9 \mathrm{~mol}$ photons $\mathrm{m}^{-2}$ depending on site and season (Fig. 5). Daily photon flux below the canopy varied seasonally (Table 2), being high and similar in April and June (pairwise comparisons; all $p>0.762$ ), but substantially lower in September $(p<0.04)$. Daily photon flux did not differ between sites with different wave exposure (all $\mathrm{p}>0.240$ ).

\section{Epiphyte species composition, diversity and biomass}

We found 19 species of epiphytic macroalgae on the stipe of Laminaria hyperborea, most of these (16) being red algae. The 6 dominant species, in terms of biomass, were Ptilota gunneri, Membranoptera alata, Delesseria sanguinea, Cystoclonium purpureum and Palmaria palmata, which made up $\sim 60$ to $65 \%$ of the total epiphyte biomass. Species composition was affected significantly by wave exposure $(\mathrm{p}=0.021$; Table 3$)$, but not by season or interaction between wave exposure and season. The biomass of $D$. sanguinea, $M$. alata, C. purpureum and P. palmata was significantly higher at sites with high wave exposure whereas $P$. gunneri and Porphyra sp. were more abundant at low wave exposure (Table 4). Species richness $(S)$ decreased from 11.6 at low exposure sites to 9.2 at high exposure sites (Table 3).

The epiphyte biomass ranged from 0.06 to $0.15 \mathrm{~g} \mathrm{DW} \mathrm{cm}^{-1}$ stipe (Fig. 6A), but varied neither with wave exposure nor with season (Table 5). Total biomass of epiphytes per stipe (Fig. 6B) ranged from 3.6 to $11.7 \mathrm{~g} \mathrm{DW}$ and was, in contrast, affected significantly by both wave exposure and season, but not by their interaction (Table 5). The total epiphyte biomass on plants from high exposure sites was almost $50 \%$ higher than that on plants from low exposure sites, because the latter had shorter stipes than those

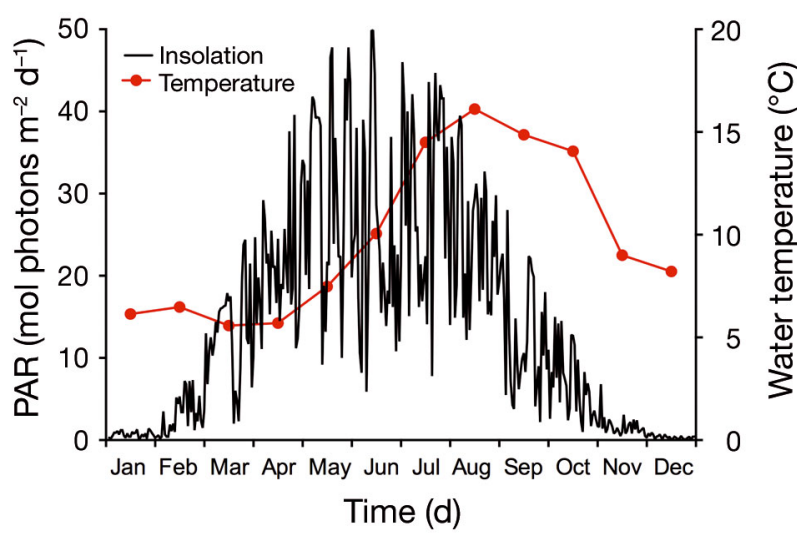

Fig. 3. Daily solar irradiance (photosynthetically active radiation, PAR) and water temperature near the study site from January to December 2006. Light data were obtained from LanbruksMeterologisk Tjeneste, site Tingvoll $\left(62^{\circ} 91^{\prime} \mathrm{N}\right.$, $\left.08^{\circ} 17^{\prime} \mathrm{E}\right)$, while water temperatures were obtained from Institute of Marine Research (www.imr.no/forskning/forsk ningsdata/stasjoner/), site Bud (62 $\left.54^{\prime} \mathrm{N}, 06^{\circ} 54^{\prime} \mathrm{E}\right)$ 


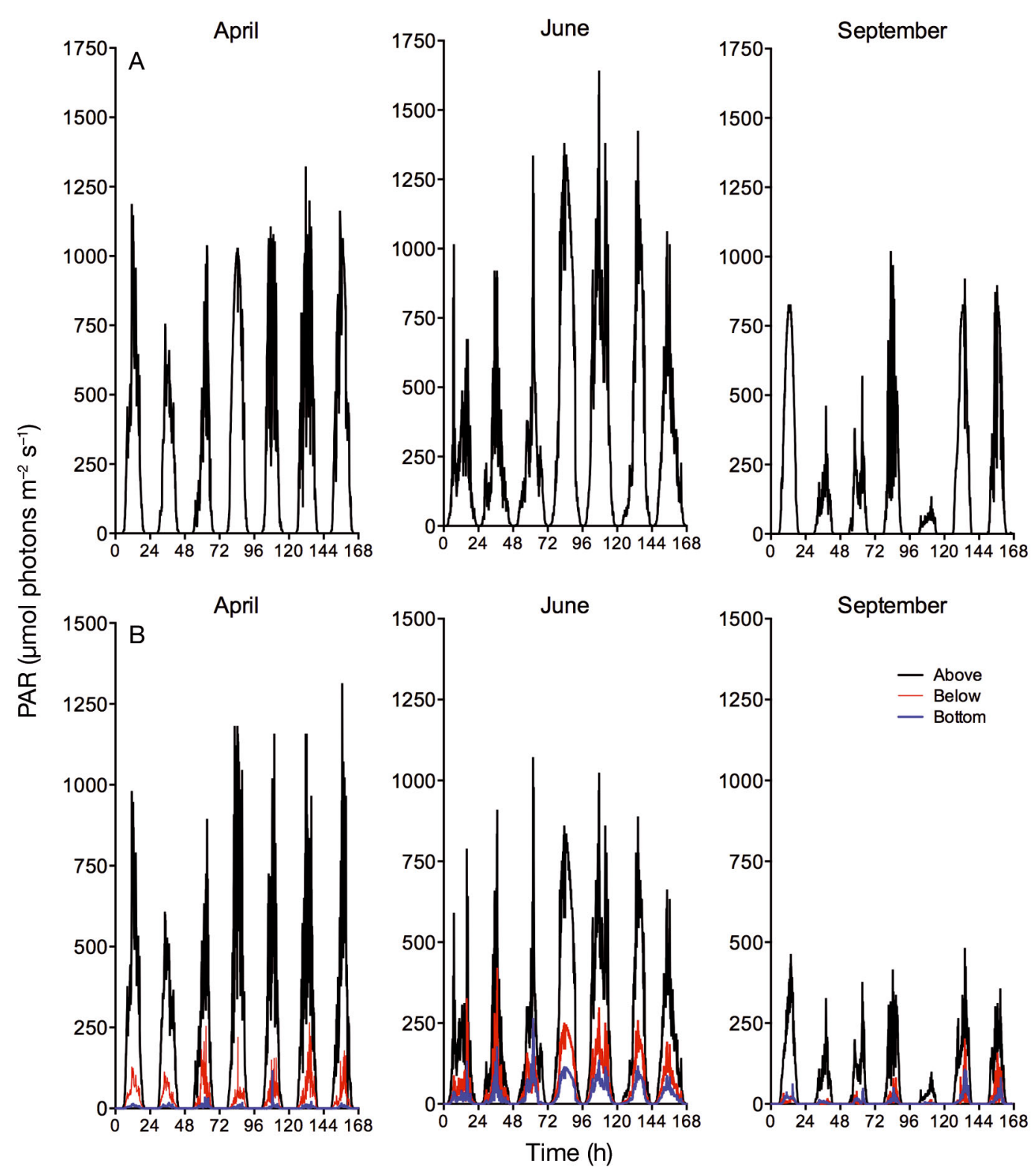

Fig. 4. (A) Surface irradiance (photosynthetically active radiation, PAR) measured at the roof of the field station during the 3 sampling events in 2006. (B) Down-welling light intensity in the water above and below the canopy layer at one of the study sites (L1) during the 3 sampling events in 2006. Light measurements taken just above the canopy (black line); and sub-canopy level (red: halfway between the canopy layer and the seafloor, blue: just above the seafloor)

from high exposure sites. The epiphyte biomass per stipe increased from April to June, but decreased from June to September. Epiphyte biomass per unit area of seafloor (Fig. 6C) ranged from 25 to $120 \mathrm{~g} \mathrm{DW}$ $\mathrm{m}^{-2}$ and was affected by wave exposure and season, but not by their interaction (Table 5). Biomass per unit seafloor was almost twofold larger at sites with high exposure than at low exposure due to a combination of longer stipes and a higher density of canopy plants at sites with high wave exposure. The biomass of epiphytes per unit area was higher in summer than in spring and fall.

\section{PI-relations}

Photosynthetic parameters $\left(P_{\max }, \alpha, R_{\mathrm{D}}, I_{\mathrm{C}}\right.$ and $\left.I_{\mathrm{K}}\right)$ were estimated from fits to the data by Eq. (3). All regressions were highly significant $(p<0.001)$ and $R^{2}$ was always larger than 0.89 . When expressed per unit algal DW biomass, these parameters were remarkably similar across sites and seasons. The maximum photosynthetic rate $\left(P_{\max }\right)$ ranged from 0.94 to $1.88 \mu \mathrm{mol} \mathrm{O}_{2} \mathrm{~g}^{-1} \mathrm{DW} \mathrm{min}^{-1}$ (Fig. 7A), while the light use efficiency $(\alpha)$ ranged from 0.06 to $0.13 \mu \mathrm{mol} \mathrm{O}_{2}$ $\mathrm{g}^{-1}$ DW $\mathrm{min}^{-1}$ ( $\mu \mathrm{mol}$ photons $\left.\mathrm{m}^{-2} \mathrm{~s}^{-1}\right)^{-1}$ (Fig. 7B). Nei- 

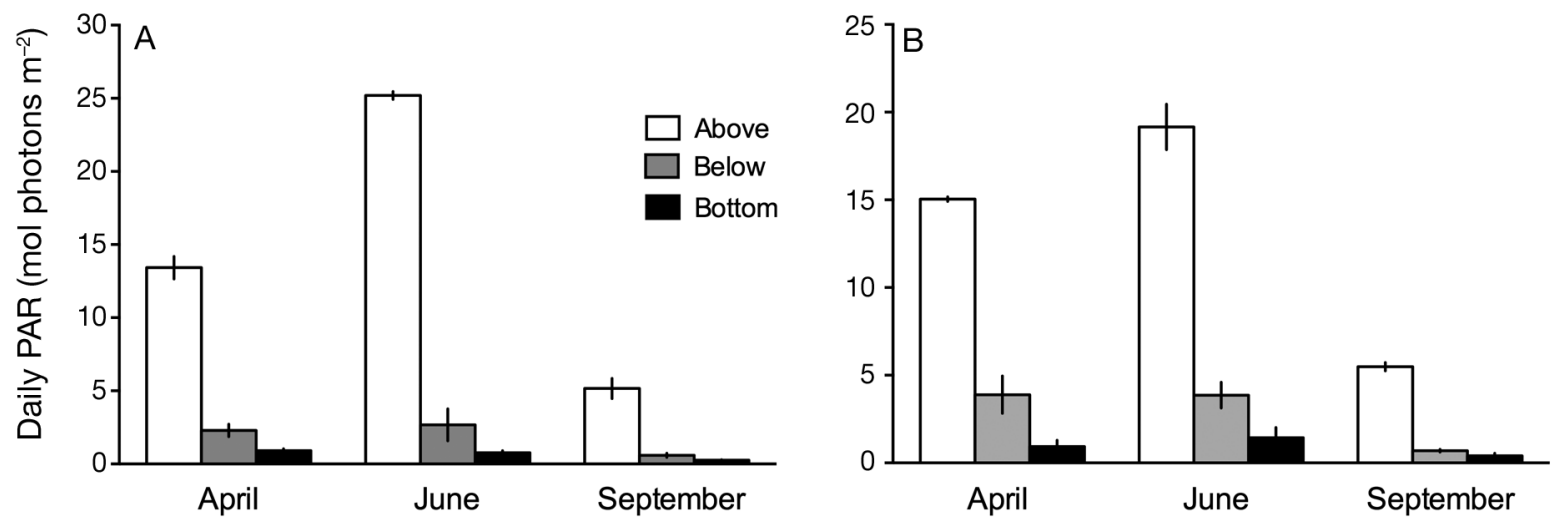

Fig. 5. Light availability in the Laminaria hyperborea forest. Average daily light intensity (photosynthetically active radiation, $\mathrm{PAR}$ ) above and below the canopy layer and next to the seafloor during the 3 sampling months at sites with (A) low and (B) high wave exposure. Means \pm 1 SD (across sites; $\mathrm{n}=3$ )

Table 2. Permutational ANOVA analysis testing the effect of season, wave exposure and position (above or below the canopy) on light intensity above and below the canopy layer of Laminaria hyperborea

\begin{tabular}{|llrrrr|}
\hline $\begin{array}{l}\text { Response } \\
\text { variable }\end{array}$ & Source & df & MS & Pseudo- $F$ & $p$ \\
\hline Light & & & & \\
$\quad$ intensity & Weason $(S)$ & 2 & 207.24 & 191.26 & $<0.001$ \\
& Position $(P)$ & 1 & 0.03 & 0.02 & 0.880 \\
& $S \times W$ & 2 & 926.01 & 854.64 & $<0.001$ \\
& 2 & 7.06 & 6.51 & 0.005 \\
& $W \times P$ & 4 & 116.50 & 107.52 & $<0.001$ \\
& $2 \times P$ & 6.41 & 5.92 & 0.005 \\
& $S \times W \times P$ & 4 & 9.60 & 8.36 & $<0.001$ \\
& Residual & 36 & 1.08 & & \\
\hline
\end{tabular}

Table 3. Permutational MANOVA and ANOVA analyses testing the effect of season and wave exposure on species composition and species richness among macroalgal epiphytes on Laminaria hyperborea stipes

\begin{tabular}{|llrrrc|}
\hline $\begin{array}{l}\text { Response } \\
\text { variable }\end{array}$ & Source & df & MS & Pseudo- $F$ & $\mathrm{p}$ \\
\hline Species & Season $(S)$ & 2 & 529 & 1.432 & 0.144 \\
composition & Wave exposure $(W)$ & 1 & 1028 & 2.783 & 0.021 \\
& $S \times W$ & 2 & 273 & 0.738 & 0.735 \\
& Residual & 12 & 369 & & \\
Species & Season $(S)$ & 2 & 9.4 & 2.012 & 0.170 \\
richness & Wave exposure $(W)$ & 1 & 24.5 & 5.250 & 0.043 \\
& $S \times W$ & 2 & 6.5 & 1.393 & 0.263 \\
& Residual & 12 & 4.7 & & \\
\hline
\end{tabular}

Seasonal changes in $\alpha$ and $R_{\mathrm{D}}$ caused the light compensation point $\left(I_{C}\right)$ to increase almost threefold from $\sim 3$ to $\sim 9 \mu \mathrm{mol}$ photons $\mathrm{m}^{-2} \mathrm{~s}^{-1}$ from April to September (Fig. 7D, Table 6), whereas wave exposure had no significant effect on $I_{\mathrm{C}}$. The saturating irradiance $\left(I_{\mathrm{K}}\right)$ averaged at $\sim 22 \mu \mathrm{mol}$ photons $\mathrm{m}^{-2} \mathrm{~s}^{-1}$ across sites and seasons and was neither affected significantly by wave exposure nor by season (Fig. 7E, Table 6).

\section{Net productivity (NPP) by epiphytes}

NPP of epiphytic macroalgae was not affected significantly by wave exposure, but varied across seasons (Table 6). NPP measured over several successive days during each sampling event increased from 0.075 and $0.085 \mathrm{~g}$ DW stipe ${ }^{-1} \mathrm{~d}^{-1}$ in April to 0.106 and $0.121 \mathrm{~g} \mathrm{DW}$ stipe $^{-1} \mathrm{~d}^{-1}$ in June for each wave exposure level (Fig. 8A). The epiphytic algae experienced, in contrast, a net loss of weight at both levels of wave exposure $\left(-0.038\right.$ and $-0.041 \mathrm{~g} \mathrm{DW}$ stipe $^{-1} \mathrm{~d}^{-1}$,

ther $P_{\max }$ nor $\alpha$ were affected significantly by wave exposure or season (Table 6). Respiration rate $\left(R_{\mathrm{D}}\right)$ ranged from 0.25 to $0.72 \mu \mathrm{mol} \mathrm{O}_{2} \mathrm{~g}^{-1} \mathrm{DW} \mathrm{min}^{-1}$ (Fig. 7C), and was not affected significantly by wave exposure (Table 6), but increased almost threefold from April and June to September (pairwise comparisons, $\mathrm{p}<0.02$ ). respectively) in September. Daily NPP per unit area of seafloor (Fig. 8B) was not affected significantly by wave exposure, but varied seasonally (Table 6). Daily NPP at low and high exposure sites increased from 0.7 and $0.9 \mathrm{~g} \mathrm{DW} \mathrm{m}^{-2}$ in April to 1.1 and $1.2 \mathrm{~g} \mathrm{DW} \mathrm{m}^{-2}$ in June and decreased to -0.3 and $-0.4 \mathrm{~g} \mathrm{DW} \mathrm{m}^{-2}$ during the survey in September. 
Table 4. Results from the SIMPER analysis showing which species contributed most to the observed dissimilarity (Diss: 28.3) in species composition among stem epiphytes on Laminaria hyperborea from sites with low and high wave exposure (exp.), respectively

\begin{tabular}{|c|c|c|c|c|}
\hline \multirow[t]{2}{*}{ Species } & \multicolumn{2}{|c|}{ Biomass (g DW $\mathrm{cm}^{-1}$ ) } & \multirow{2}{*}{$\begin{array}{c}\text { Diss } \\
(\text { Mean } \pm \mathrm{SD})\end{array}$} & \multirow{2}{*}{$\begin{array}{c}\text { Contribution } \\
(\%)\end{array}$} \\
\hline & Low exp. & High exp. & & \\
\hline Ptilota gunneri & 25.3 & 21.1 & $4.45 \pm 1.48$ & 13.6 \\
\hline Palmaria palmata & 0.1 & 4.2 & $4.03 \pm 1.5$ & 12.3 \\
\hline Membranoptera alata & 6.5 & 17.9 & $3.84 \pm 1.72$ & 11.7 \\
\hline Delesseria sanguinea & 6.2 & 9.6 & $2.78 \pm 1.21$ & 8.5 \\
\hline Cystoclonium pupureum & 5.1 & 5.7 & $2.72 \pm 0.87$ & 8.3 \\
\hline Porphyra purpurea & 0.9 & 0 & $2.08 \pm 0.56$ & 6.4 \\
\hline
\end{tabular}

Estimated daily NPP for each month through 2006 is shown in Fig. 9. NPP became positive in late winter (February-March) and increased through spring and early summer, where it peaked in May (1.2 and $1.3 \mathrm{~g} \mathrm{DW} \mathrm{m}^{-2}$ at low and high exposure sites, respectively). It remained high and relatively constant over the summer, but declined abruptly and approached zero in late summer (August). Finally, NPP became negative in September, when the water temperature was high and the surface irradiance decreased rapidly (Fig. 3), and it remained negative through fall and winter. Integration of the monthly estimates of NPP resulted in an annual production by these epiphytes equal to 97 and $42 \mathrm{~g} \mathrm{DW} \mathrm{m}^{-2}$ for sites with low and high wave exposure, respectively. The low annual NPP at high wave exposure sites was mainly caused by large negative values at these sites during fall and winter.

\section{DISCUSSION}

Laminaria hyperborea forests harbor a rich invertebrate fauna (Edwards 1980, Schultze et al. 1990, Christie et al. 2003, 2009). The feeding habitats of these invertebrates include herbivory, detritivory and omnivory (Norderhaug \& Christie 2011). Potentially fast-growing macroalgae, occurring attached on the kelp or free-floating within the kelp forest, may constitute an important alternative source of food for many of the herbivores and omnivores because fresh kelp represents a relatively poor food source (Norderhaug et al. 2003). Small and potentially fast-growing macroalgae occur both as freefloating specimens, under-story algae attached to the seafloor and as epiphytes on the stipes and fronds of kelp, and the total biomass of these algae per unit area of seafloor may approach that of functionally similar algae in shallow coastal and estuarine systems (e.g. Valiela et al. 1997). The relatively large biomass of small, potentially fast-growing macroalgae within the kelp forests suggests that these may contribute significantly to the productivity and, thus, serve as an important food source for secondary producers.

Most of the epiphytes attached to the stipes of L. hyperborea were red algae with a biomass ranging from 25 to $120 \mathrm{~g} \mathrm{DW} \mathrm{m}^{-2}$ seafloor. The species com-
Fig. 6. Biomass of epiphytic algae growing on the stipes of Laminaria hyperborea at sites with low and high wave exposure during spring, summer and fall. Biomass is (A) per $\mathrm{cm}$ of stipe, (B) per stipe, and (C) per $\mathrm{m}^{2}$ of seafloor. Data are means \pm 1 SD (across sites; $\mathrm{n}=3$ ) 
Table 5. Permutational ANOVA analyses testing the effect of season and wave exposure on the biomass of stem epiphytes on Laminaria hyperborea

\begin{tabular}{|c|c|c|c|c|c|}
\hline $\begin{array}{l}\text { Response } \\
\text { variable }\end{array}$ & Source & $\mathrm{df}$ & MS & Pseudo- $F$ & $\mathrm{p}$ \\
\hline \multirow{4}{*}{$\begin{array}{l}\text { Biomass } \mathrm{cm}^{-1} \\
\text { of stipe }\end{array}$} & Season $(S)$ & 2 & 0.004 & 2.405 & 0.154 \\
\hline & Wave exposure $(W)$ & 1 & 0.004 & 2.100 & 0.183 \\
\hline & $S \times W$ & 2 & 0.001 & 0.384 & 0.690 \\
\hline & Residual & 12 & 0.002 & & \\
\hline \multirow{4}{*}{$\begin{array}{l}\text { Total biomass } \\
\text { stipe }^{-1}\end{array}$} & Season $(S)$ & 2 & 29.68 & 4.763 & 0.037 \\
\hline & Wave exposure $(W)$ & 1 & 47.82 & 7.674 & 0.018 \\
\hline & $S \times W$ & 2 & 7.76 & 1.244 & 0.304 \\
\hline & Residual & 12 & 6.23 & & \\
\hline \multirow{4}{*}{$\begin{array}{l}\text { Total biomass } \\
\mathrm{m}^{-2} \\
\text { seafloor }\end{array}$} & Season $(S)$ & 2 & 3531 & 3.878 & 0.044 \\
\hline & Wave exposure $(W)$ & 1 & 12817 & 14.071 & 0.004 \\
\hline & $S \times W$ & 2 & 1714 & 1.881 & 0.200 \\
\hline & Residual & 12 & 911 & & \\
\hline
\end{tabular}

position and biomass corresponded well to those found in other studies on epiphytes in L. hyperborea (Norton et al. 1977, Whittick 1983). The total epiphyte biomass per $\mathrm{m}^{2}$ seafloor doubled with increasing wave exposure, as also reported by Norderhaug et al. (2012), which indicates that macroalgal epiphytes may have better conditions under high wave exposure. The epiphyte biomass per cm stipe did not, however, vary significantly among low and high exposure sites, so the observed differences in biomass per unit area of seafloor must have been caused by site-specific variations in stipe density and length
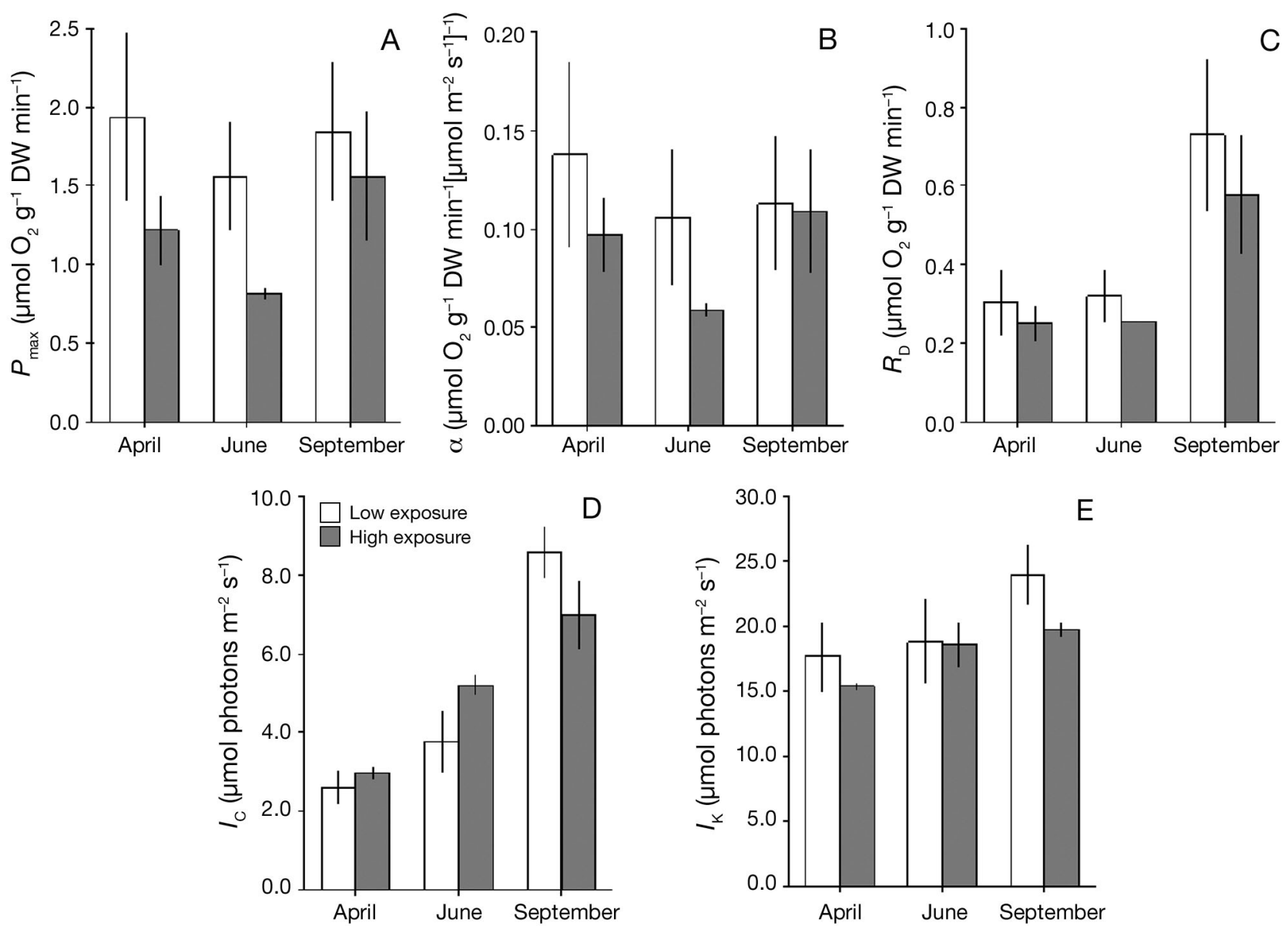

Fig. 7. Epiphytes. Photosynthetic properties for epiphytic algae on Laminaria hyperborea from sites with low and high wave exposure during spring, summer and fall, respectively. (A) Maximum photosynthetic rate $\left(P_{\max }\right)$; (B) light utilization efficiency $(\alpha)_{i}(\mathrm{C})$ dark respiration $\left(R_{\mathrm{D}}\right) ;(\mathrm{D})$ light compensation points $\left(I_{\mathrm{C}}\right) ;(\mathrm{E})$ light saturating points $\left(I_{\mathrm{K}}\right)$. Data are means \pm 1 SD $($ across sites; $\mathrm{n}=3$ ) 
Table 6. Permutational ANOVA analyses testing the effect of season and wave exposure on photosynthetic characteristics and net productivity (NPP) of stipe epiphytes on Laminaria hyperborea. $P_{\max }$ : max. photosynthetic rate; $\alpha$ : light utilization efficiency; $R_{\mathrm{D}}$ : dark respiration rate; $I_{\mathrm{C}}$ : light compensation point; $I_{\mathrm{K}}$ : light saturation point; DW: dry weight

\begin{tabular}{|c|c|c|c|c|c|}
\hline $\begin{array}{l}\text { Response } \\
\text { variable }\end{array}$ & Source & df & MS & Pseudo- $F$ & $\mathrm{p}$ \\
\hline \multirow{4}{*}{$\begin{array}{l}P_{\max } \text { (per unit } \\
\text { DW) }\end{array}$} & Season $(S)$ & 2 & 0.93 & 1.01 & 0.388 \\
\hline & Wave exposure $(W)$ & 1 & 3.60 & 3.90 & 0.072 \\
\hline & $S \times W$ & 2 & 0.23 & 0.25 & 0.786 \\
\hline & Residual & 12 & 0.92 & & \\
\hline \multirow{4}{*}{$\begin{array}{l}\alpha \text { (per unit } \\
\text { DW) }\end{array}$} & Season $(S)$ & 2 & 0.80 & 0.74 & 0.502 \\
\hline & Wave exposure $(W)$ & 1 & 1.78 & 1.64 & 0.221 \\
\hline & $S \times W$ & 2 & 0.34 & 0.31 & 0.734 \\
\hline & Residual & 12 & 1.08 & & \\
\hline \multirow{4}{*}{$\begin{array}{l}R_{\mathrm{D}} \text { (per unit } \\
\text { DW) }\end{array}$} & Season $(S)$ & 2 & 4.62 & 7.93 & 0.007 \\
\hline & Wave exposure $(W)$ & 1 & 0.61 & 1.04 & 0.327 \\
\hline & $S \times W$ & 2 & 0.07 & 0.13 & 0.877 \\
\hline & Residual & 12 & 0.58 & & \\
\hline \multirow[t]{4}{*}{$I_{\mathrm{C}}$} & Season $(S)$ & 2 & 38.78 & 39.84 & $<0.001$ \\
\hline & Wave exposure $(W)$ & 1 & 0.03 & 0.03 & 0.870 \\
\hline & $S \times W$ & 2 & 3.47 & 3.56 & 0.060 \\
\hline & Residual & 12 & 0.97 & & \\
\hline \multirow[t]{4}{*}{$I_{\mathrm{K}}$} & Season $(S)$ & 2 & 42.88 & 3.36 & 0.071 \\
\hline & Wave exposure $(W)$ & 1 & 22.67 & 1.78 & 0.211 \\
\hline & $S \times W$ & 2 & 5.90 & 0.46 & 0.636 \\
\hline & Residual & 12 & 12.76 & & \\
\hline \multirow[t]{4}{*}{$\operatorname{NPP}\left(\mathrm{m}^{-2} \mathrm{~d}^{-1}\right)$} & Season $(S)$ & 2 & 4.25 & 37.42 & $<0.001$ \\
\hline & Wave exposure $(W)$ & 1 & $<0.01$ & 0.05 & 0.835 \\
\hline & $S \times W$ & 2 & 0.02 & 0.17 & 0.849 \\
\hline & Residual & 12 & 0.11 & & \\
\hline
\end{tabular}

cies have provided similar results (Norton et al. 1977, Gerard 1984), although the amount of down-welling light in Macrocystis forests is larger than in L. hyperborea forests (Gerard 1984). Studies have shown that wave action may improve sub-canopy light conditions in Macrocystis stands (Wing et al. 1993). The same could be true for Laminaria, but plant density, frond size and LAI increase with increasing wave exposure in L. hyperborea (Pedersen et al. 2012). The net result is that light penetration, and, thus the amount of sub-canopy light, was practically similar across sites with low and high wave exposure.

Low light availability below the canopy suggests that sub-canopy algae must be shade acclimated. The photosynthetic profiles of the epiphytic assemblages supported this expectation. Shade acclimation in algae occurs through reduced levels of RUBISCO, increased pigment concentration and/or altered pigment composition (Lobban \& Harrison 1997). These changes lead to lower $P_{\text {max }}$, higher photosynthetic efficiency $(\alpha)$ and lower respiration, resulting in rather than by variations in resource availability (e.g. space, light, nutrients).

The availability of light below the canopy varied seasonally, but was generally $<20 \%$ of the irradiance reaching the canopy layer. Studies on the light conditions in stands of L. hyperborea and other kelp spea lower light compensation point $\left(I_{C}\right)$. The photosynthetic parameters of the epiphytic assemblages showed signs of shade acclimation when compared to those of 16 individual, sub-tidal, red macroalgae (Mathieson \& Norall 1975, Johansson \& Snoeijs 2002). The average $P_{\max }$ of these 16 species was
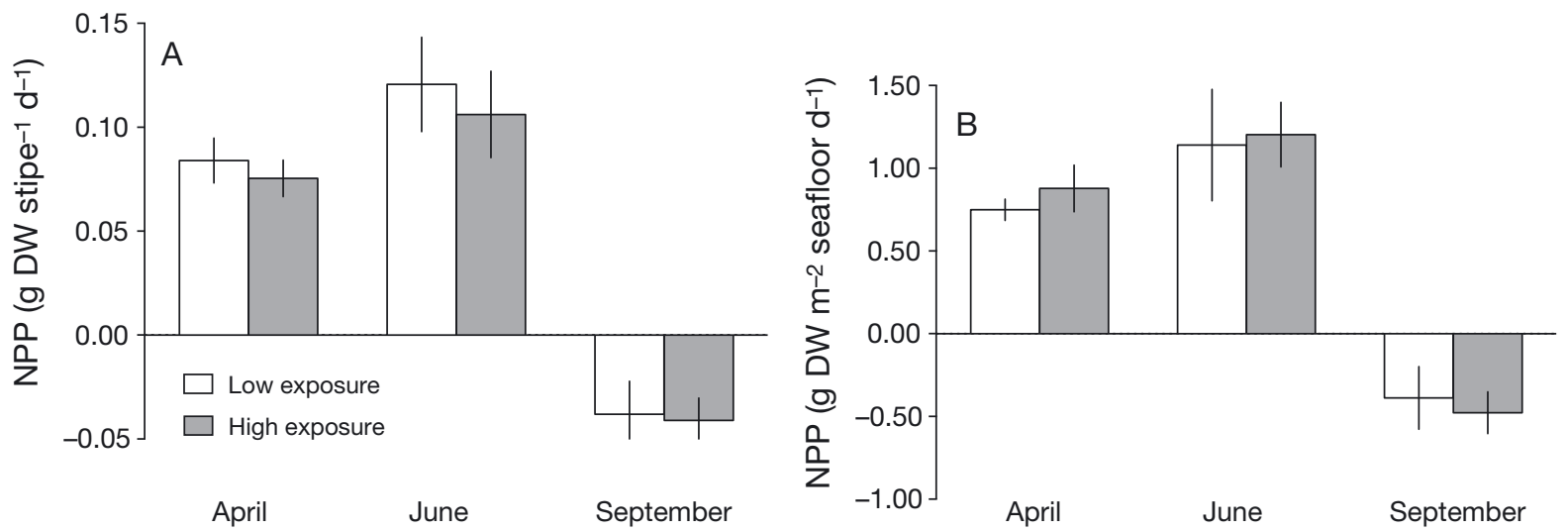

Fig. 8. Net primary production (NPP) of epiphytic macroalgae on the stipes of Laminaria hyperborea from sites with low and high wave exposure during spring, summer and fall, respectively. NPP is: (A) per stipe; and (B) per $\mathrm{m}^{-2}$ of seafloor. Data are means \pm 1 SD (across sites; $\mathrm{n}=3$ ) 


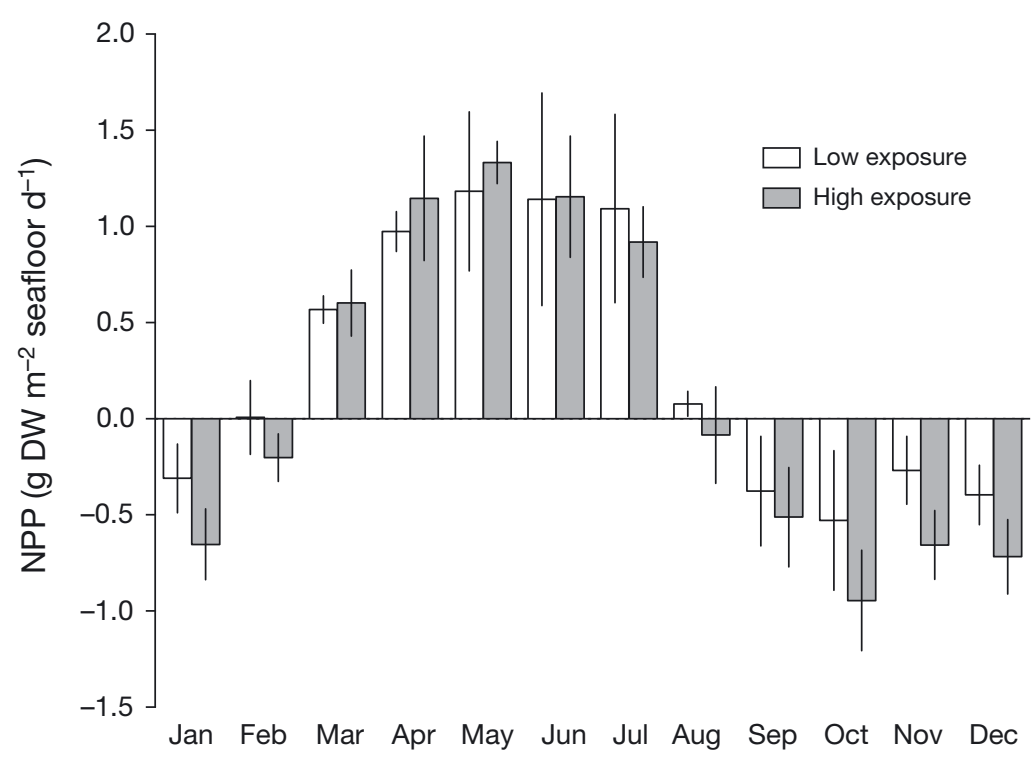

Fig. 9. Estimated daily net primary production (NPP) of epiphytic macroalgae on the stipes of Laminaria hyperborea through 2006 from sites with low (white) and high (grey) wave exposure. Data are means \pm 1 SD (across sites; $\mathrm{n}=3$ )

almost threefold higher than that of the epiphytic assemblages from this study (4.5 vs. $1.5 \mu \mathrm{mol} \mathrm{O} \mathrm{g}^{-1}$ DW $\min ^{-1}$ ), while $\alpha$ of the epiphytic assemblages was ca. twofold higher than for the 16 algae $(0.103 \mathrm{vs}$. $0.066 \mu \mathrm{mol} \mathrm{O}_{2} \mathrm{~g}^{-1} \mathrm{DW} \mathrm{min}^{-1}\left[\mu \mathrm{mol}\right.$ photons $\mathrm{m}^{-2}$ $\left.\left.\mathrm{s}^{-1}\right]^{-1}\right)$. Dark respiration rates $\left(R_{\mathrm{D}}\right)$ of the 16 algae were also twofold higher than among the epiphytic assemblages (0.88 vs. $0.44 \mu \mathrm{mol} \mathrm{O}_{2} \mathrm{~g}^{-1} \mathrm{DW} \mathrm{\textrm {min } ^ { - 1 }}$ ). The epiphytic assemblages had consequently much lower $I_{\mathrm{C}}$ values than the average of the 16 species of red algae (2.3-8.5 vs. $21.2 \mu \mathrm{mol}$ photons $\left.\mathrm{m}^{-2} \mathrm{~s}^{-1}\right)$.

The measured NPP of the epiphytic assemblages was generally low, and especially so in September (Fig. 8), although the epiphytes showed signs of shade acclimation. The biomass specific productivity in spring and summer corresponded to $P: B$ ratios in the range of $0.012-0.014$ and $0.010-0.019 \mathrm{~d}^{-1}$, respectively. The availability of sub-canopy light was almost the same in April and June, so we suggest that the reduced productivity in June may have been caused by increasing self-shading among the epiphytes (epiphyte biomass increased during early summer) or by increasing nutrient limitation as often observed during summer in coastal waters (e.g. Pedersen 1995, Pedersen \& Borum 1996, Pedersen et al. 2010). In contrast, the low and negative NPP values observed in September most likely resulted from a combination of high water temperatures and decreasing light availability below the canopy. High water temperature in September $\left(16^{\circ} \mathrm{C}\right)$ likely caused a significant increase in respiration and thereby a threefold increase in the light requirements $\left(I_{\mathrm{C}}\right)$ of the epiphytes. At the same time, sub-canopy light dropped substantially due to a combination of lower surface irradiance and increasing surface reflection and/or light absorption in the water column.

NPP of the epiphytes increased from February to July, but declined to zero in August and remained negative throughout fall and winter. Annual NPP was rather low, but seasonal variations in NPP corresponded well with observed seasonal variations in biomass that increased from spring to summer and decreased from summer to fall. The annual net production of epiphytes was quantitatively insignificant (i.e. 96 and $42 \mathrm{~g} \mathrm{DW} \mathrm{m}^{-2}$ ) when compared to that of L. hyperborea (1370 to $2590 \mathrm{~g} \mathrm{DW} \mathrm{m}^{-2}$ depending on site and wave exposure; Pedersen et al. 2012). The low epiphytic production suggests that the large epiphyte biomass on old stipes needs years to accumulate. This is supported by the cover estimates in Fig. 2; the stipes of young kelp individuals (age 0 to 3 yr) were completely devoid of visible epiphytes and only plants older than 4 to 6 yr had a high epiphyte cover (rank 2-3).

The low production attained in summer and especially in fall was surprising. Our productivity measurements were carried out using intact epiphyte communities attached to their substrate (stipes) to maintain any internal self-shading and/or natural gradients within the communities. Besides macroalgae, these communities include heterotrophic organisms such as bacteria, protozoans and mezofauna that may enhance community respiration and, thus, lower net community photosynthesis and thereby the estimated net production. The same accounts for the stipes of L. hyperborea that served as substrate for the epiphytes. These may also potentially have contributed with net respiration and/or photosynthesis during the incubations, although we were unable to detect any significant $\mathrm{O}_{2}$ consumption or production when measuring a few 'clean' stipes. A substantial contribution to community respiration by heterotrophic organisms and/or the stipes should lead to biomass specific respiration rates that are higher than those for single algal specimens. We conducted photosynthetic light response measurements on 3 macroalgal species from the kelp forest in April 2006 for other purposes, but the dark res- 
piration rates of these algae (Odonthalia dentata $=$ $0.293 \mu \mathrm{mol} \mathrm{O} \mathrm{O}_{2} \mathrm{~g}^{-1} \mathrm{DW} \mathrm{min}^{-1}$, Delessira sanguinea $=$

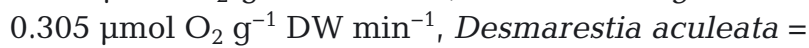
$0.557 \mu \mathrm{mol} \mathrm{O} \mathrm{g}^{-1} \mathrm{DW} \mathrm{min}^{-1}$; M.F. Pedersen unpubl. data) were in the same range, or even higher, than those for the epiphytic assemblages during the same period $\left(0.250\right.$ to $\left.0.302 \mathrm{O}_{2} \mathrm{~g}^{-1} \mathrm{DW} \mathrm{min}^{-1}\right)$. This comparison suggests that heterotrophic organisms and/or the substrate (stipe) contributed marginally to total community respiration, and that epiphytic macroalgae seemed to be the major drivers of respiration and photosynthesis in these communities. Our productivity measurements of the epiphytic macroalgae therefore seem reliable.

Within the kelp forest, there is also attached epilithic algae as well as drift macroalgae that become entangled between the stipes. The maximum biomass of these algae is found during summer, and is highest at sites with low wave exposure $(81 \pm 99$ vs. $19 \pm 8 \mathrm{~g} \mathrm{DW} \mathrm{m}^{-2}$ at high exposure; M. F. Pedersen unpubl data). A large proportion of these are unattached algae that may drift in and out of the kelp meadows, which makes it difficult to evaluate their importance for total primary production. Light availability at the seafloor was lower than along the stipes, making epilithic and drift algae more likely to contribute less to total productivity than epiphyte assemblages on the stipes. Epiphytic macroalgae (mainly Ceramium sp. and Polysiphonia sp.) are also found on the upper side of Laminaria fronds. The biomass of these algae can be quite large (September: $113 \pm$ 56 and $11 \pm 5 \mathrm{~g} \mathrm{DW} \mathrm{m}^{-2}$ seafloor at low wave and high wave exposure, respectively; M. F. Pedersen unpubl. data). Light conditions here are much better than below the canopy so the productivity of these epiphytes may be high. The lamina of L. hyperborea is annual and young laminas were completely devoid of visible epiphytes in April (M. F. Pedersen pers. obs.), while most of the frond epiphytes observed in September will be lost during late fall and winter when the old laminas erode and disappear. The biomass of frond epiphytes in September thus represents a crude estimate of the annual production of these algae. Frond epiphytes could hereby contribute with an input of organic matter similar to that of epiphytes on the stipes, especially at low wave exposure. Incorporating thin, relatively fast-growing macroalgae that live as epiphytes on stipes or fronds of L. hyperborea as well as epilithic or drift algae within the kelp meadows may contribute to the total primary production of the entire kelp forest, although their relative importance seems marginal relative to that of kelp itself.
The invertebrate fauna related to L. hyperborea exceed 4000 ind. per plant (Norderhaug et al. 2012), and most of this fauna is related to the epiphytic algae. The annual secondary production ranges from 68 to $308 \mathrm{~g} \mathrm{DW} \mathrm{m}^{-2}$, depending on site and wave exposure (Norderhaug \& Christie 2011). Few herbivores feed directly on live kelp; rather, they feed on kelp detritus enriched by microflora and/or on associated epiphytic red algae (Fredriksen 2003, Norderhaug et al. 2003). The secondary production by the potential herbivores (i.e. isopods, amphipods and gastropods) amounts to 15-172 $\mathrm{g} \mathrm{DW} \mathrm{m} \mathrm{m}^{-2} \mathrm{yr}^{-1}$, depending on the site (from Table 3 in Norderhaug \& Christie 2011). It is clear that the food intake required to support such secondary production far exceeds the production of epiphytic macroalgae in the system. This indicates that epiphytic algae on L. hyperborea play a minor role as a food source for the associated fauna, and that the fauna uses the epiphytes for shelter rather than for food (Norderhaug 2004).

The low productivity of the epiphytic macroalgae on $L$. hyperborea means that the relatively large epiphyte biomass on the stipe has to accumulate over many years. Also, the loss of epiphytic algae due to physical disturbance (detachment) and grazing must be relatively small. We conclude that these epiphytes contribute little to the total productivity of the kelp forest, and that they most likely play a marginal nutritional role for the associated invertebrate grazers.

Acknowledgements. This project was supported by grant no 2005-01-0522 from the Carlsberg Foundation and grant no 173468 from the Norwegian Research Council. We thank Trine Bekkby (Norwegian Institute for Water Research) for providing estimated wave exposure levels in the Molde archipelago and Thomas Allan Rayner, Roskilde University for helping us to improve the English. We also thank 4 anonymous referees for valuable and constructive suggestions for improvements to the first version of this manuscript.

\section{LITERATURE CITED}

Abdullah MI, Fredriksen S (2004) Production, respiration and exudation of dissolved organic matter by the kelp Laminaria hyperborea along the west coast of Norway. J Mar Biol Assoc UK 84:887-894

Anderson MJ, Gorley RN, Clarke KR (2008) PERMANOVA+ for PRIMER. Guide to software and statistical methods. PRIMER-E, Plymouth

Baly ECC (1935) The kinetics of photosynthesis. Proc R Soc Lond B Biol Sci 117:218-239

> Bekkby T, Isachsen PE, Isæus M, Bakkestuen V (2008) GIS modeling of wave exposure at the seabed: a depthattenuated wave exposure model. Mar Geod 31:117-127

Buesa RJ (1980) Photosynthetic quotient of marine plants. Photosynthetica 14:337-342 
Christie H, Jørgensen NM, Norderhaug KM, WaageNielsen E (2003) Species distribution and habitat exploitation of fauna associated with kelp (Laminaria hyperborea) along the Norwegian coast. J Mar Biol Assoc UK 83:687-699

Christie H, Norderhaug KM, Fredriksen S (2009) Macrophytes as habitat for fauna. Mar Ecol Prog Ser 396: 221-233

Davies EC, Moss D, Hill OM (2004) EUNIS habitat classification revised 2004. Report to the European Environment Agency. European Topic Centre on Nature Protection and Biodiversity, Paris. http://eunis.eea.europa.eu/references $/ 1473$

Duarte CM (1992) Nutrient concentrations of aquatic plants: patterns across species. Limnol Oceanogr 37:882-889

Edwards A (1980) Ecological studies of the kelp, Laminaria hyperborea, and its associated fauna in south-west Ireland. Ophelia 19:47-60

Fredriksen S (2003) Food web studies in a Norwegian kelp forest based on stable isotope $\left(\delta^{13} \mathrm{C}\right.$ and $\left.\delta^{15} \mathrm{~N}\right)$ analysis. Mar Ecol Prog Ser 260:71-81

- Gerard VA (1984) The light environment in a giant kelp forest: influence of Macrocystis pyrifera on spatial and temporal variability. Mar Biol 84:189-195

Gundersen $\mathrm{H}$, Christie $\mathrm{H}$, de Wit $\mathrm{H}$, Norderhaug KM, Bekkby T, Walday MG (2010) $\mathrm{CO}_{2}$ uptake in marine habitats: an investigation. NIVA Rep OR-6070 (in Norwegian with an English summary)

Henley WJ (1993) Measurement and interpretation of photosynthetic light-response curves in algae in the context of photoinhibition and diel changes. J Phycol 29:729-739

Isæus M (2004) Factors structuring Fucus communities at open and complex coastlines in the Baltic Sea. PhD thesis, Stockholm University

> Johansson G, Snoeijs P (2002) Macroalgal photosynthetic responses to light in relation to thallus morphology and depth zonation. Mar Ecol Prog Ser 244:63-72

Kain JM (1963) Aspects of the biology of Laminaria hyperborea. II. Age, weight and length. J Mar Biol Assoc UK 43:129-151

Lobban CS, Harrison PJ (1997) Seaweed ecology and physiology. Cambridge University Press, Cambridge

Long MH, Rheuban JE, Berg P, Zieman JC (2012) A comparison and correction of light intensity loggers to photosynthetically active radiation censors. Limnol Oceanogr Methods 10:416-424

Mathieson AC, Norall TL (1975) Physiological studies of subtidal red algae. J Exp Mar Biol Ecol 20:237-247

Norderhaug KM (2004) Use of red algae as hosts by kelpassociated amphipods. Mar Biol 144:225-230

Norderhaug KM, Christie H (2011) Secondary production in a Laminaria hyperborea kelp forest and variation according to wave exposure. Estuar Coast Shelf Sci 95:135-144

Norderhaug KM, Fredriksen S, Nygaard K (2003) Trophic importance of Laminaria hyperborea to kelp forest con-

Editorial responsibility: Just Cebrian,

Dauphin Island, Alabama, USA sumers and the importance of bacterial degradation to food quality. Mar Ecol Prog Ser 255:135-144

Norderhaug KM, Christie H, Andersen GS, Bekkby T (2012) Does the diversity of kelp forest macrofauna increase with wave exposure? J Sea Res 69:36-42

Norton TA, Hiscock K, Kitching JA (1977) The ecology of Lough Ine: XX. The Laminaria forest at Carrigathorna. J Ecol 65:919-941

Pedersen MF (1995) Nitrogen limitation of photosynthesis and growth across aquatic plant communities in a Danish estuary (Roskilde Fjord). Ophelia 41:261-272

$>$ Pedersen MF, Borum J (1996) Nutrient control of algal growth in estuarine waters. Nutrient limitation and the importance of nitrogen requirements and nitrogen storage among phytoplankton and species of macroalgae. Mar Ecol Prog Ser 142:261-272

> Pedersen MF, Borum J, Fotel FL (2010) Phosphorus dynamics and limitation of fast- and slow-growing temperate seaweeds in Oslofjord, Norway. Mar Ecol Prog Ser 399: 103-115

Pedersen MF, Nejrup LB, Fredriksen S, Christie H, Norderhaug KM (2012) Effects of wave exposure on population structure, demography, biomass and productivity of the kelp Laminaria hyperborea. Mar Ecol Prog Ser 451:45-60

Rinde E, Sjøtun K (2005) Demographic variation in the kelp Laminaria hyperborea along a latitudinal gradient. Mar Biol 146:1051-1062

> Rosenberg G, Littler DS, Littler MM, Oliveira EC (1995) Primary production and photosynthetic quotients of seaweeds from Sao Paulo State, Brazil. Bot Mar 38:369-377

Santamaria L, van Vierssen W (1997) Photosynthetic temperature responses of fresh- and brackish-water macrophytes: a review. Aquat Bot 58:135-150

Schultze K, Janke K, Krüss A, Weidemann W (1990) The macrofauna and macroflora associated with Laminaria hyperborea at the island of Helgoland (German Bight, North Sea). Helgol Mar Res 44:39-51

Sjøtun K, Fredriksen S (1995) Growth allocation in Laminaria hyperborea (Laminariales, Phaeophyceae) in relation to age and wave exposure. Mar Ecol Prog Ser 126: 213-222

> Thomas DN, Wiencke C (1991) Photosynthesis, dark respiration and light independent carbon fixation of endemic Antarctic macroalgae. Polar Biol 11:329-337

> Valiela I, McClelland J, Hauxwell J, Behr P, Hersh D, Foreman K (1997) Macroalgal blooms in shallow estuaries: controls and ecophysiological and ecosystem consequences. Limnol Oceanogr 42:1105-1118

Whittick A (1983) Spatial and temporal distributions of dominant epiphytes on the stipes of Laminaria hyperborea (Gunn.) Fosl. (Phaeophyta: Laminariales) in SE Scotland. J Exp Mar Biol Ecol 73:1-10

> Wing SR, Leichter JJ, Denny MW (1993) A dynamic model for wave-induced light fluctuations in a kelp forest. Limnol Oceanogr 38:396-407

Submitted: March 31, 2014; Accepted: August 25, 2014 Proofs received from author(s): November 14, 2014 